\title{
Progress and Prospects of Forest Ecological Asset Research
}

\author{
Tingling Li, Kangning Xiong *, Shan Yang, Haiyan Liu, Yao Qin and Zhifu Wang
}

\begin{abstract}
School of Karst Science, State Engineering Technology Institute for Karst Desertification Control of China, Guizhou Normal University, Guiyang 550001, China; tinglingli2021@163.com (T.L.); yangshand1@163.com (S.Y.); lhy1679454421@163.com (H.L.); qin333yao444@163.com (Y.Q.); wzfkst@163.com (Z.W.)

* Correspondence: xiongkn@163.com
\end{abstract}

Citation: Li, T.; Xiong, K.; Yang, S.; Liu, H.; Qin, Y.; Wang, Z. Progress and Prospects of Forest Ecological Asset Research. Sustainability 2022, 14, 395. https://doi.org/10.3390/ su14010395

Academic Editor: Ivo Machar

Received: 29 October 2021

Accepted: 28 December 2021

Published: 30 December 2021

Publisher's Note: MDPI stays neutral with regard to jurisdictional claims in published maps and institutional affiliations.

Copyright: (c) 2021 by the authors Licensee MDPI, Basel, Switzerland. This article is an open access article distributed under the terms and conditions of the Creative Commons Attribution (CC BY) license (https:/ / creativecommons.org/licenses/by/ $4.0 /)$.

\begin{abstract}
In recent years, in the face of the deterioration of the ecological environment, the research on forest ecological assets (FEA) has increasingly become a focal area of ecological research. To understand the current research progress and future prospects, this paper classifies and summarizes the main progress and achievements related to FEA in terms of theoretical studies, index systems, technical methods, and accounting models. In view of the existing research results, this paper proposes seven key scientific and technical problems and prospects to be solved, including the unification of the concept of ecological assets, the focus of future research on FEA, the construction of an evaluation index system according to local conditions, the integration of data assimilation methods that complement ground and remote sensing observations, the study of the spatial and temporal heterogeneity of forest ecological assets, the study of the net value of FEA, and the preservation and appreciation of FEA.
\end{abstract}

Keywords: forests; ecosystems; ecological assets; ecosystem services

\section{Introduction}

The research results of the United Nations "Millennium Ecosystem Assessment" project concluded that 15 of the 24 ecosystem service functions in the four major categories are continuously degrading, and $60 \%$ of the ecosystems on which humans depend are in a state of continuous degradation. Moreover, the increasing external pressures such as strong human interference and climate change will lead to the occurrence and development of desertification on a global scale [1]. The first IPBES Global Assessment, released in 2019, reveals widespread accelerating declines in our planet's biodiversity and life-support systems; this will threaten species viability, human security, physical and mental health, food, and livelihood security [2]. This suggests that we need to pay more attention to natural ecosystems. As the main terrestrial ecosystem, forest is the largest and most widely distributed ecosystem on land, with the most complex composition and the most abundant material resources, and not only does it provide raw materials for human agricultural and industrial production, but more importantly, it supports and sustains the life- support system of the earth. Maintaining and conserving the forest ecosystem is the basis for achieving the sustainable development of the whole of society [3,4].

Forests are complex and dynamic ecosystems that provide a wide range of ecological, economic, and sociocultural values to society. These values include many commodities and amenities such as water production, soil conservation, carbon sequestration, wildlife habitat, provision of forage, and a variety of wood products [5]. Forests also provide a variety of cultural ecosystem services (ES), such as recreation, landscape aesthetics, or cultural heritage [6]. In addition, they act as natural barriers to buffer the effects of climate change and natural disasters, such as windbreak and sand fixation, landslide and debris flow prevention, and flood mitigation [7]. In recent years, special emphasis has been placed on the non-material values of forests. But regardless of the type of classification used, the tangible and intangible benefits that society derives from it. The services discussed here are 
not unique to forests and can be derived from other land covers/uses as well (though in smaller quantities).

As forest ecological assets (FEA) are not fully "captured" in commercial markets or quantified in the same way as economic services and manufacturing capital, they are often given too little weight in decision-making and the public is almost completely unaware of society's dependence on forest ecosystems [8]; such neglect may ultimately undermine the sustainability of humans in the biosphere [9]. Revealing the value of FEA is a prerequisite for economic decision-making to maintain life-support functions [10]. Valuation is necessary for an informed allocation of limited resources in order to maximize the benefits to society [11]; if these factors are internalized in the decision-making process, it can strengthen the country's economic justification for forest protection [12]. Therefore, the valuation of FEA is the foundation for ensuring the coordinated development of ecosystems and socio-economic systems [13].

In 1921, Parker and Burgess introduced the concept of ecological carrying capacity in the Journal of Human Ecology, which means "the maximum limit of the existence of a certain number of individuals under certain environmental conditions (mainly the combination of ecological factors such as living space, nutrients and sunlight)" [14]. The individuals here are not just people, but should also include other creatures, such as ducks [15] and deer [16]. The connotation of forest carrying capacity (FCC) includes two basic meanings. Firstly, it refers to the capacity of forest ecosystem, which is its self-sustaining and self-regulating capacity, and is the supporting part of forest carrying capacity. Secondly, it refers to the development capacity of the socio-economic subsystem in the forest ecosystem, which is the pressure part of FCC [17]. The study of FCC is a requirement for sustainable forest development. Only by developing and utilizing forest resources within the scope of FCC can the sustainability of forests be ensured. Regional FCC is crucial to regional social and economic development [18].

FEA indicate FCC [19]. The subject of evaluation of FEA is people, and the evaluation of FEA is the evaluation of the driving force of sustainable development of human society supported by the natural environment. The development of FEA and its related research will reveal the principle of mutual influence and change between human economic and social development and the ecological environment, for example, the trade-off relationship between flood control and timber production, and prompt human beings to explore the sustainable development path of being resource-efficient, ecologically sound, economically sustainable, and socially harmonious in their practical activities [20,21]. FEA are the basis for the formation of forest eco-benefits and gross ecosystem value [22], and FEA accounting provides the basis for the proposal of strategies for improving FCC. Forest resources are important ecological assets that support human social development. Exploring the value accounting of FEA is of great significance to the rational use and effective protection of forest resources.

This study comprehensively analyzes the existing research on FEA, and this paper does the following: (1) calculates the annual distribution of the literature, classes the research phase, and creates the keyword co-occurrence map; (2) summarizes the current research progress and achievements related to FEA; (3) and proposes seven key scientific issues, mainly related to the problems in the research processes of FEA and FCC.

\section{Materials and Methods}

The literature search was based on the China National Knowledge Infrastructure (CNKI) database and the Web of Science (WOS) Core database. Web of Science is a large comprehensive, multidisciplinary, core journal citation database. It includes three major citation databases (Science Citation Index (SCI), Social Sciences Citation Index (SSCI), and Arts and Humanities Citation Index (A\&HCI)) and two fact-based databases of chemical information (Current Chemical Reactions (CCR) and Index Chemicus (IC)). The CNKI database is the world's largest continuously and dynamically updated full-text database of 
Chinese journals. These two databases basically represent an overview of the literature in English and Chinese.

In the CNKI database, we used "topic" as the search item, and "Forest" as the search word for the first search. Among the results, "ecological assets" and "ecological carrying capacity" were used as the search words for the second search. In the WOS Core database, "forest" was used as the search word for the first search, and "ecological assets" and "ecological carrying capacity" were used as the search words for the second search. The search time range was the maximum time range of the database. Finally, the retrieved Chinese and English literature was manually screened according to the research content of this article.

The articles were screened using three steps (Figure 1). Firstly, the article was screened to remove duplicate articles; this process detected and removed three articles, leaving 398 articles to be taken to the next level of analysis. Secondly, 41 articles were excluded by manually screening article titles and abstracts by the researchers. Thirdly, 32 articles were removed by reading the full text and eliminating forest fires, species invasions, children's perceptions, and so on. Finally, a total of 317 articles made it to the final analysis.

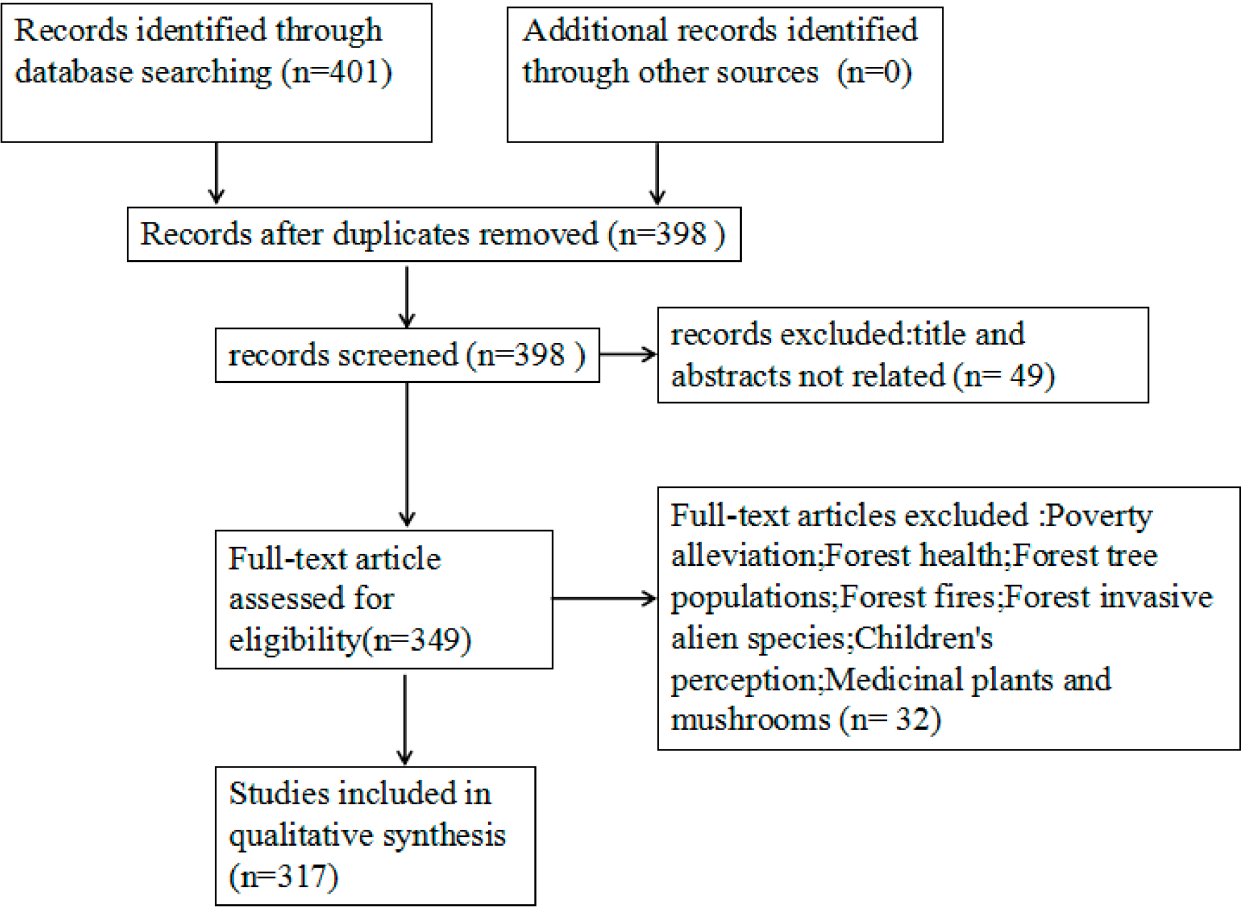

Figure 1. Flow of article selection process.

By means of the above search and screening, a total of 317 Chinese and English literature-related research articles were obtained. There were 184 English literature and 133 Chinese literature results, including 273 journal articles, 27 master's theses, 11 doctoral theses, and 6 conferences. It should be noted that the references listed at the end of the text are all cited in this study and the rest of the literature is not included. Based on these results, we analyzed the literature using statistical analysis software. The literature statistics were done in Excel, the graphs were made using Origin software, and the analysis performed in both enabled us to obtain the annual distribution of the literature and to identify different trends in the growth of the literature. A map of the country distribution of the literature was obtained and analyzed in relation to the area of forests in different countries. The keywords plots were analyzed from the graphs using VOSviewer software, and keywords density mapping and keywords co-occurrence mapping were obtained. 


\section{Literature Distribution}

\subsection{Annual Distribution of the Literature}

As shown in Figure 2, the annual distribution of the research literature on forest ecological assets can be roughly divided into three stages (Table 1). The first stage is from 1997 to 2001, the literature available is relatively small and the research is still at an embryonic stage with insufficient depth. Related research increased from 2002 to 2011, and many domestic scholars made their own insights on ecological assets-this phase was the growth phase. Between 2012 and 2020 is a period of rapid growth, with rapid development of ecological assets, ecosystem services, and ecological carrying capacity, and a gradual increase in integrated multidisciplinary research. Moreover, the trends of the English literature and the overall literature were basically the same.

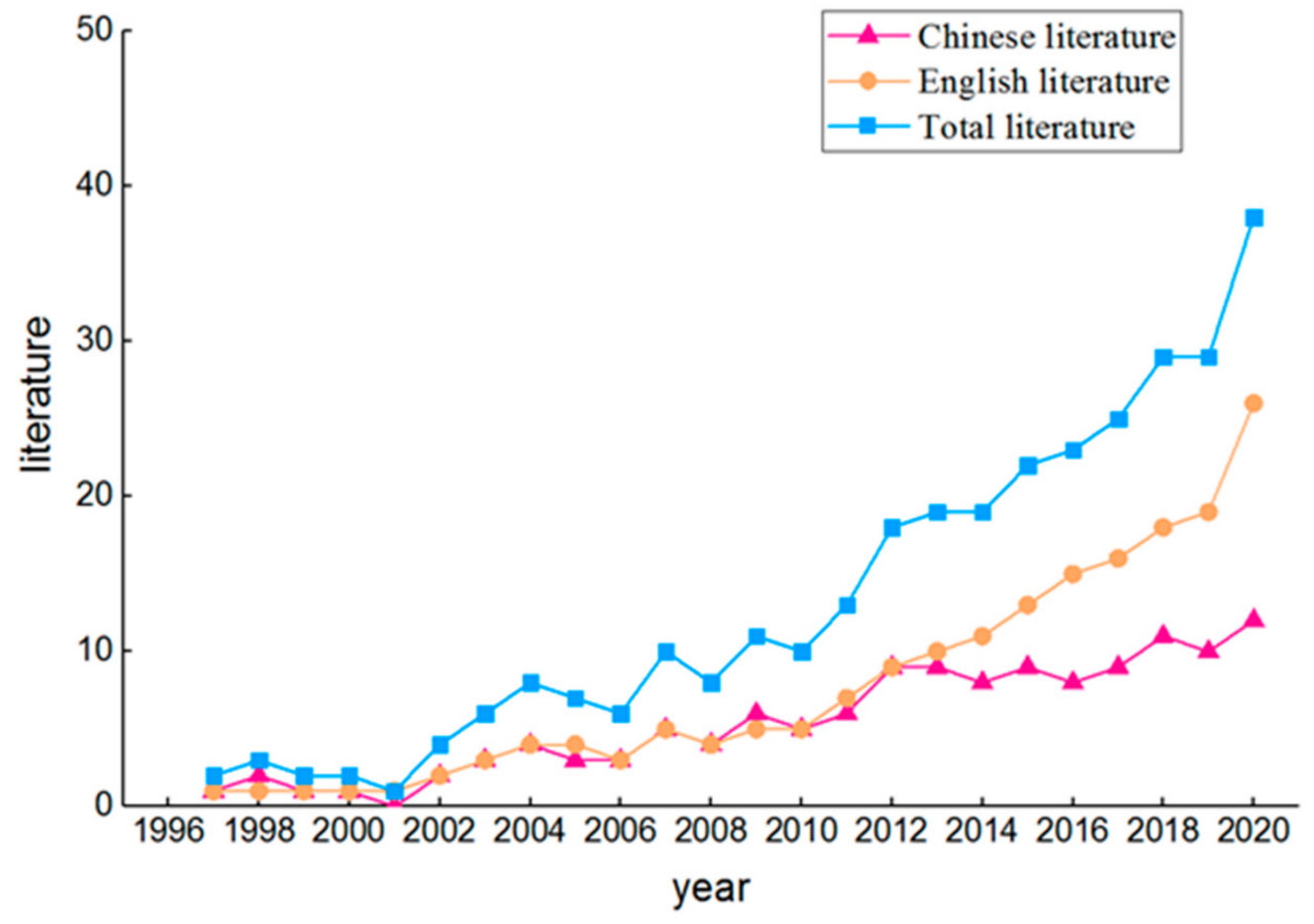

Figure 2. Annual distribution of the literature.

\subsection{Country Distribution of the Literature}

The country distribution of the literature is illustrated in Figure 3. Due to space limitations, only areas with four or more research articles are listed. China and the United States have the most research on forest ecological assets, accounting for $30 \%$ of the total, followed by Australia and Brazil, with $8 \%$ and $7 \%$, respectively, and there are also more studies on Canada, Mexico, Scotland, Switzerland, Finland, Netherland, Italy, England, and Germany. Comparing the forest areas of the countries in the world (Figure 4), we find that countries with large forest areas such as DR Congo and Indonesia do not appear in Figure 3; instead, many European countries with small forest areas such as England and Italy are represented. This may indicate that interest is not linearly related to presence, but to perceived scarcity. On the other hand, there are more studies in developed countries than in developing countries. 
Table 1. Division of research stages.

\begin{tabular}{|c|c|c|c|}
\hline Research Stage & Research Content & Development Background & Main Characteristics \\
\hline $\begin{array}{l}\text { Embryonic Stage } \\
\quad(1997-2001)\end{array}$ & $\begin{array}{l}\text { Concept of ecological assets } \\
\text { and selection of asset } \\
\text { accounting indicators. }\end{array}$ & $\begin{array}{l}\text { The relevant theoretical research is } \\
\text { still in the embryonic stage, and the } \\
\text { research depth is insufficient. }\end{array}$ & $\begin{array}{l}\text { Less literature was found and } \\
\text { was mostly for large-scale } \\
\text { ecological asset accounting. }\end{array}$ \\
\hline $\begin{array}{l}\text { Growth Stage } \\
(2002-2011)\end{array}$ & $\begin{array}{l}\text { The concept of ecological } \\
\text { assets was first used more } \\
\text { frequently, and the research } \\
\text { has gradually deepened. }\end{array}$ & $\begin{array}{l}\text { Ecosystem quality is being } \\
\text { emphasized globally across } \\
\text { disciplines, and research on } \\
\text { ecosystem services and ecological } \\
\text { assets continues to diversify. }\end{array}$ & $\begin{array}{l}\text { Relevant articles are published } \\
\text { every year, and the depth of } \\
\text { research has deepened, with } \\
\text { research on both the total value } \\
\text { of regional ecological assets and } \\
\text { the value of single ecosystem } \\
\text { service functions. }\end{array}$ \\
\hline $\begin{array}{l}\text { Rapid-Growth Stage } \\
\text { (2012-Today) }\end{array}$ & $\begin{array}{l}\text { Ecological asset accounting } \\
\text { method and case study and } \\
\text { ecological compensation. }\end{array}$ & $\begin{array}{l}\text { Ecological assets, ecosystem services, } \\
\text { and ecological compensation are } \\
\text { developing rapidly, and } \\
\text { multidisciplinary integrated research } \\
\text { is gradually increasing. }\end{array}$ & $\begin{array}{l}\text { There are many articles } \\
\text { published every year and the } \\
\text { research on ecological assets } \\
\text { and carrying capacity is } \\
\text { relatively mature, but there is } \\
\text { no empirical research on small- } \\
\text { and medium-scale study areas. }\end{array}$ \\
\hline
\end{tabular}

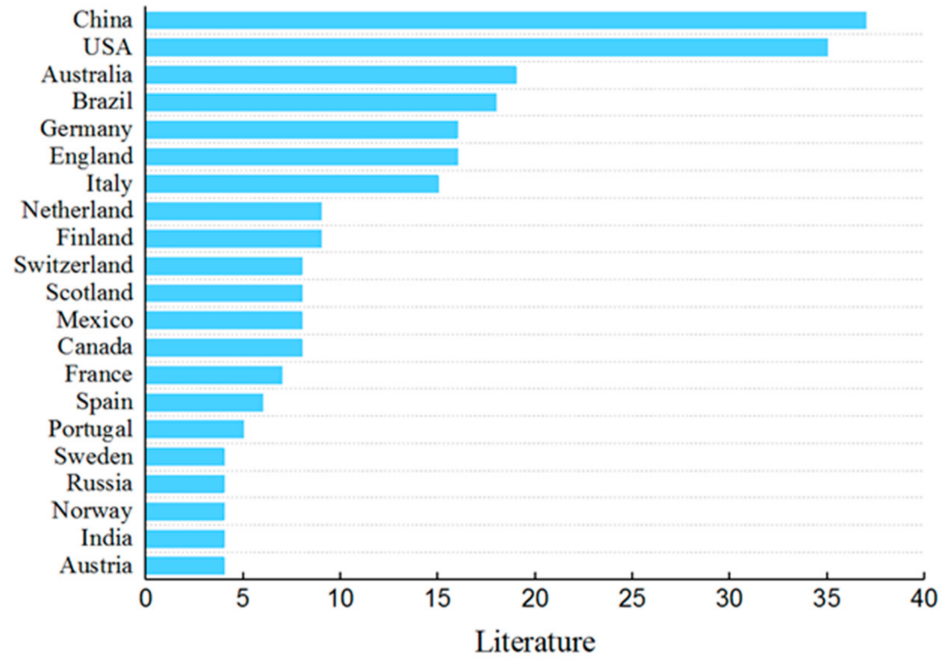

Figure 3. Literature by country and territory.

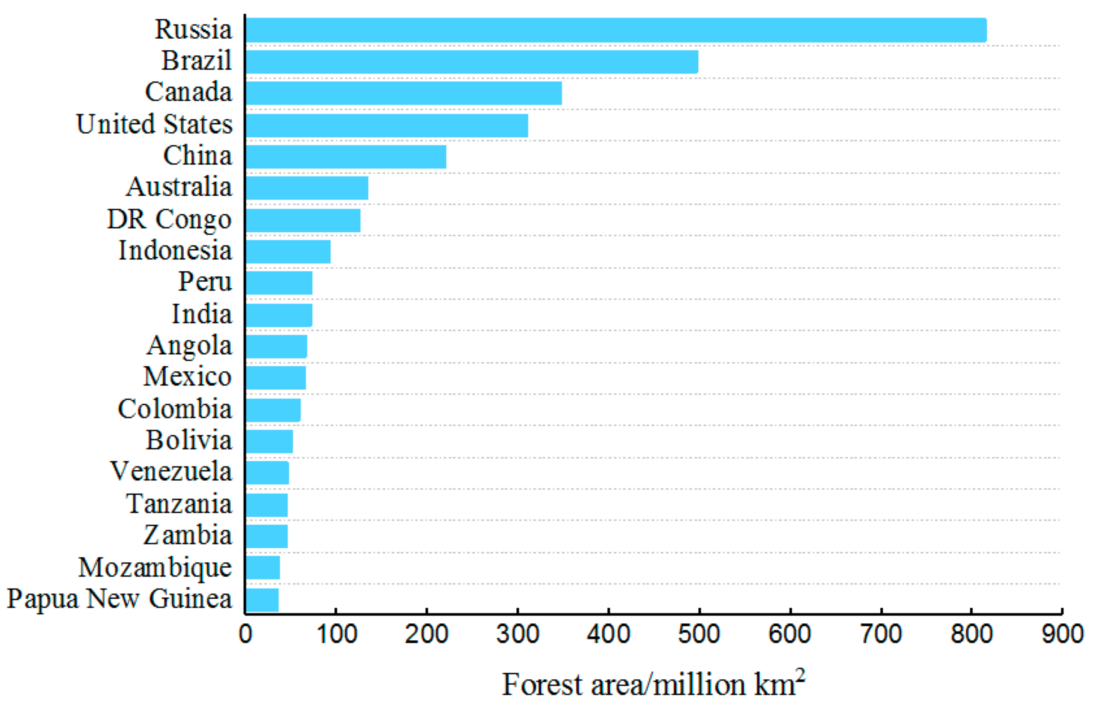

Figure 4. World forest area in 2020: top 20 countries (data from FAO official database). 


\subsection{Literature Keywords Mapping}

Keywords carry the most important and core information, and the analysis of keywords helps to understand the research hotspots in the field. The literature keywords were analyzed by the VOSviewer software, and the co-occurrence frequency was set greater than 10 times to obtain Figures 5 and 6. Figure 5 shows the keywords clustering map. Cluster 1 (green) is centered on carrying capacity, effect, species, population, relationship et al. as secondary studies. Cluster 2 (red) is centered on ecosystem service and value, with conservation, benefit, policy, biodiversity, and supply et al., as secondary research. Cluster 3 (blue) is focused on China, evaluation, case study, and protection et al.; Figure 6 shows the keyword density mapping. The colors range from cool (blue) to warm (red) indicating that the higher the frequency of keyword co-occurrence, the higher the research intensity of its literature. Service and value are the most commonly used keywords, followed by capacity. Additionally, the more common words are conservation, ecological value, benefit, effect, and factor et al., which indicates that research on the conservation of ecosystems based on the results of ecological asset accounting and the factors affecting ecological carrying capacity have attracted much attention.

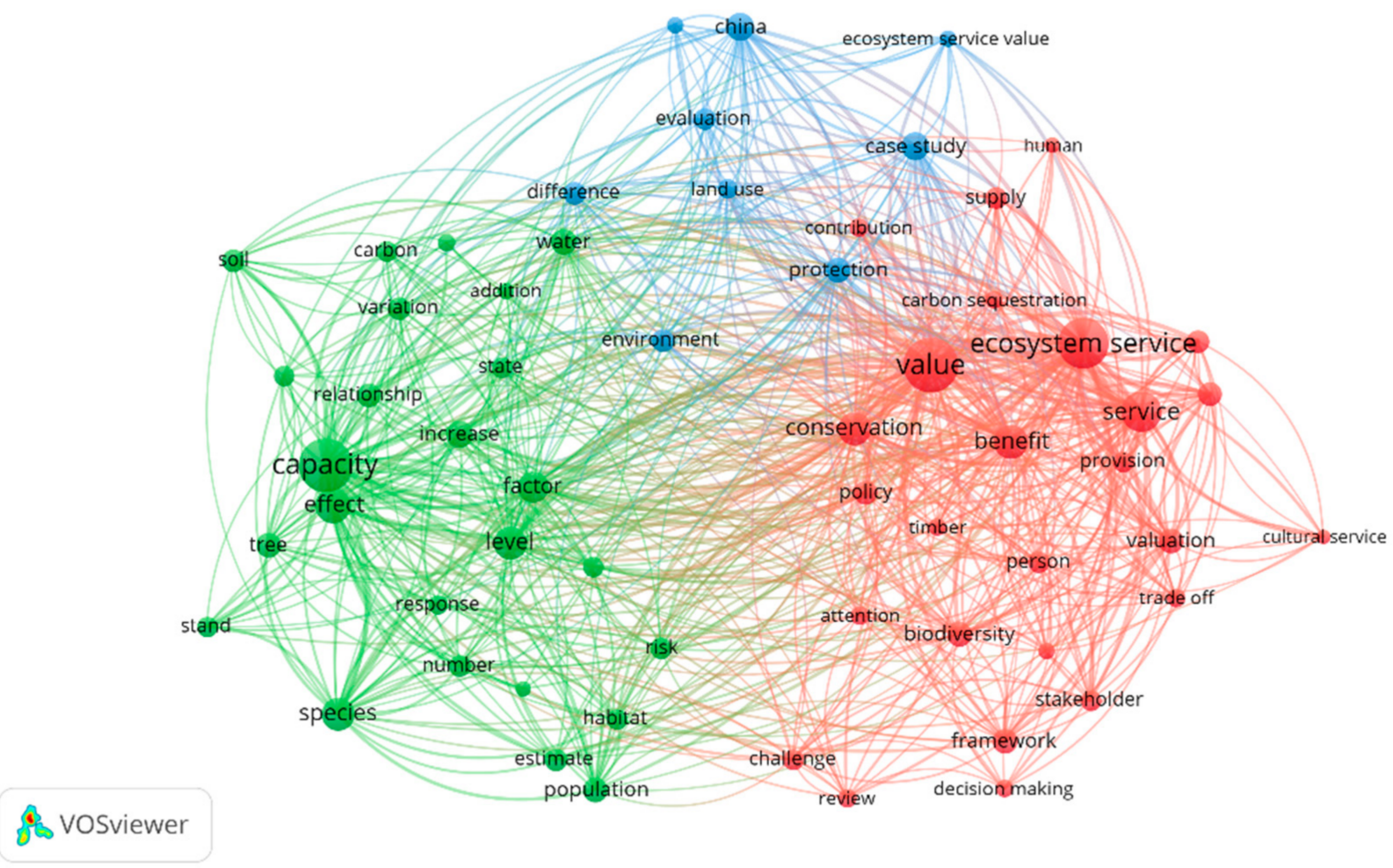

Figure 5. Keywords clustering mapping: Different colors in the map represent three clusters. The larger nodes in the map represent more occurrences, indicating a greater degree of contribution in the related field. Closely connected nodes are connected by lines, and the greater the link strength, the stronger the relationship that exists. 


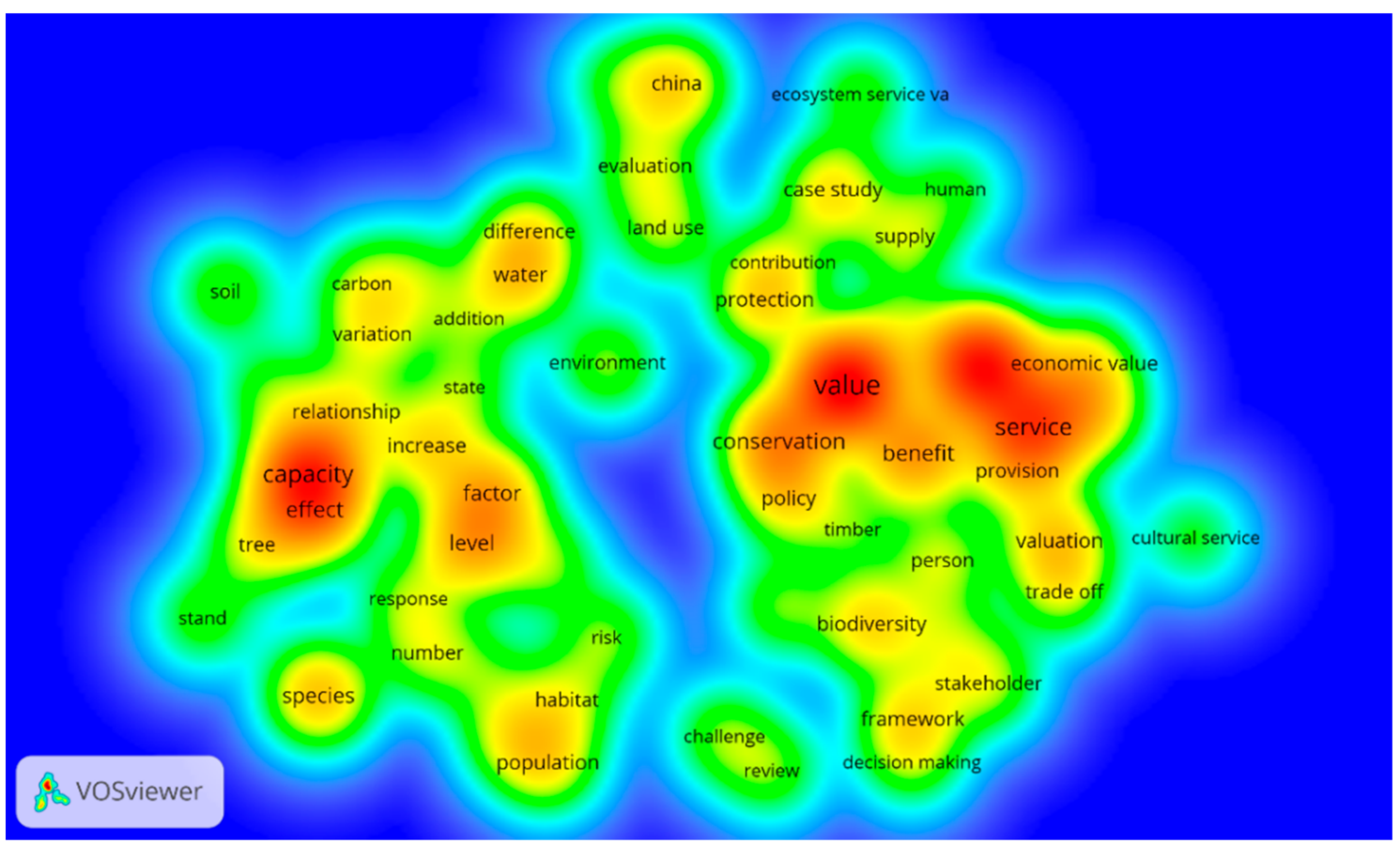

Figure 6. The density visualization of keywords: The figure shows a density map according to the frequency of keywords. Some keywords with high frequency are shown in the figure. The higher the frequency of a keyword, the larger its label, and its density will be more apparent (the color turns brighter).

\section{Main Progress and Landmark Achievements at Present}

\subsection{Theoretical Research on Related Concepts}

\subsubsection{Value, Asset, and Capital}

Value has two meanings. Firstly, things that we consider important and with value that cannot be expressed in purely economic equivalents, such as "I value biodiversity" (but I also value freedom, fairness, sustainability, income, and many other things, e.g., no amount of money can buy us a new planet). Secondly, the relative value of trade-offs-if the value of protecting biodiversity is greater than the cost of protecting biodiversity-value includes value (target) and relative value (contribution to a specific object) [23]. In traditional economics, assets refer to intangible or tangible wealth that can bring people expected economic benefits. Capital is the stock of tangible or intangible wealth used to produce other products and services, especially wealth in the form of currency or property. Capital itself is wealth; while assets are material or non-material things that have the potential to create value, assets include the concept of capital [24]. Natural assets and capital cover current forms of value that are rich in expression (e.g., atmosphere, oceans, forests, and soils, etc.) and can provide useful goods or services to humans now and in the future. This concept extends beyond traditional economics to give nature and ecosystems economic attributes characterized by value, separability, scarcity, substitutability, tradability, rights, and spatial and temporal properties [25].

\subsubsection{Ecosystem Functions and ES}

"Function" is an ecosystem-centric concept, while "ecosystem services" are humancentric. Ecosystem functions are ecological (biological, chemical, and physical) mechanisms that support the integrity of ecosystems and which do not necessarily translate into benefits for humans, and are sometimes considered to be the "support services" of ecosystems [1]. ES represent the contribution of ecosystems to human well-being, defined in terms of their specific benefits to individuals or society, and they are generally subdivided into provisioning, regulation, and cultural services [3]. ES imply human access and demand, 
so they can be valued as ecosystem goods and benefits by means of economic valuation. In the absence of human beneficiaries, ecosystem functions are not ES, in other words, ES reflect environmental conditions and human needs [26]. ES and ecosystem functions do not necessarily follow a one-to-one relationship, as one ecosystem functions can provide two or more services [27]. For example, forests not only provide timber and fruits, but also conclude Carbon storage.

\subsubsection{Forest Ecological Assets (FEA) and Forest Carrying Capacity (FCC)}

FEA are the embodiment of the value of various types of service benefits obtained by humans from the natural environment of forests, including the value of natural resources and the value of ecological service functions. FEA assessment refers to the evaluation and estimation of various types of welfare values of FEA from the perspective of economic values and using scientific methods [28]. The Chinese literature uses the concept of FEA more, and the English literature uses the concept of forest ecosystem service value more, and the research content of the two is the same, which also shows that the current understanding of FEA is not uniform.

The definition of FCC can be further divided into a broad and narrow sense. The broad sense of FCC and benign FCC, while the narrow sense of carrying capacity only refers to the limit carrying capacity of the forest, and the degree of distinction here depends on whether the cycle of the forest ecosystem is a benign promoting cycle or just maintaining the existence of this ecosystem [29,30].

\subsection{Content of FEA Accounting Indicators}

FEA are ecological assets with the values of various ecosystem service functions provided to humans in the ecological process of forest ecosystems as the core, and the value of FEA contains three levels: ecological value, socio-cultural value, and economic value. The usability is divided into use value and non-use value; use value includes the value derived from the direct use of ecosystem products and the indirect use of ecosystem services that cannot be commercialized, while non-use value includes the value of the ecosystem itself and the value of the heritage value as a legacy to future generations [4]. Some scholars classify FEA accounting indicators into two major categories, such as direct value and indirect value [31], while others divide them by functional categories, such as product provision, regulatory function, cultural function, and support function [32,33]. In summary, common forest ecological assets accounting indicators can include the following, listed in Table 2.

Table 2. Common indicators for accounting of forest ecological assets.

\begin{tabular}{ccc}
\hline Function Category & Accounting Content & Accounting Indicators \\
\hline Provisioning & Forest products & Total forestry products \\
\hline & Water conservation & Water conservation capacity \\
& Soil conservation & Soil conservation volume \\
Regulating & Wind and sand prevention & Amount of sand consolidation \\
& Water purification & Water conservation capacity \\
& Air purification & Sulfur dioxide absorption \\
& Climate regulation & Energy consumed by vegetation \\
Cultural Supporting & Recreational travel & Amount of carbon storage and oxygen release \\
\hline \multirow{2}{*}{ Carbond storage and oxygen release } & Tourism revenue \\
\hline
\end{tabular}

\subsection{Technical Methods for Monitoring FEA}

Field surveys and remote sensing are two of the most common methods used to research FEA. However, conducting large-scale field surveys is difficult. There are harsh field conditions, complex topographies, dynamic vegetation changes, and there is lim- 
ited time, manpower, and funding, preventing large-scale vegetation surveys in multiple climatic or biogeographic regions, making it difficult to predict future trends because of the reliance on field surveys in small areas. Remote sensing is increasingly being used to rapidly assess (or extrapolate from available ground truth data) ecosystem assets on a large scale. Remote sensing classification is a well-established technique widely used to monitor ecosystem changes at regional and global scales [34]. Recent techniques based on high-spatial-resolution aerial imagery and radar data can provide more detail and accuracy about forest properties than earlier techniques based on large-scale aerial photography and ground plot calibration [35]. The Space Shuttle Radar Topography Mission (SRTM) provides 30-90 m elevation and topographic resolution data and has been used for species and diversity modeling. These sensors have also been used for biodiversity mapping and modeling. The most prospective application of remote sensing is to monitor changes in ecosystems over time once ecological properties have been established for different ecosystems [36]. In addition, vegetation cover, above-ground biomass, and inversion-based productivity have been used to evaluate ecosystem quality in recent decades [37]. However, studies have rarely considered the impact of the spatial heterogeneity of environmental factors on quality, hindering the main objective of ecosystem quality assessment, which is to determine vegetation degradation compared to the original state. This inaccuracy may affect the accuracy of ecosystem assessments [38].

\subsection{FEA Accounting Methods and Models}

FEA have been a research hotspot in recent years, but a scientific, unified, and complete ES valuation system has not yet been formed due to the complexity and spatial and temporal dynamics of ES, and, furthermore, "no valuation technique is perfect, and one must simultaneously balance the requirements of analysis and the availability of data and resources" [39]. Existing assessment methods can be divided into two categories: physical quantity assessment (Table 3) and value assessment (Table 4) [40-46]. The value quantity assessment method requires less data, is simple to operate, and the assessment results are easy to understand, but is highly subjective, less comparable, and highly influenced by the spatial heterogeneity of ecosystem services. The physical quantity assessment method can assess large and complex ecosystems, and the assessment results are highly reliable, but the data are complex and require certain professional techniques [47].

Table 3. Physical quantity assessment methods - they can be divided into energy value method and modeling methods.

\section{Type}

Energy Value Method

Modeling methods
Method Classification

InVEST

MIMES

ARIES

\section{Method Introduction}

Reference

Determining the value of forest ecosystem services through the monetary conversion rate of energy values, or a functional relationship between energy values and the functional value of forest ecosystem services. Valuation of forest, freshwater, and marine ecosystem services, enabling dynamic and sustainable assessment.

Assessment of ecosystem services in the biosphere, anthroposphere, hydrosphere, lithosphere, and atmosphere.

Valuation and quantification of ecosystem services through artificial intelligence and semantic modeling, combined with relevant algorithms and spatial data.
Watanabe et al., 2014 [44]

Yang et al., 2019 [48]

Boumans et al., 2015 [49]

Villa et al., 2014 [50] 
Table 3. Cont.

\begin{tabular}{|c|c|c|c|}
\hline Type & Method Classification & Method Introduction & Reference \\
\hline & ESValue & $\begin{array}{l}\text { Assign relative values of ecosystem services } \\
\text { determined by society, managers, and } \\
\text { stakeholders, based on existing scientific } \\
\text { knowledge and stakeholder preferences. }\end{array}$ & Bagstad et al., 2013 [51] \\
\hline & CITYgreen & $\begin{array}{l}\text { Quantitative assessment of urban forest } \\
\text { ecological benefits relying on 3S technology. }\end{array}$ & Ge et al., 2020 [52] \\
\hline & iTree & $\begin{array}{l}\text { Parameter information can be set according } \\
\text { to the tree species, and the ecological benefits } \\
\text { of different tree species can be quantified } \\
\text { with easy and concise data processing. }\end{array}$ & Ge et al., 2020 [52] \\
\hline & UFORE & Quantifying forest structure and function. & Han et al., 2011 [53] \\
\hline & InFOREST & $\begin{array}{l}\text { Assessing ecosystem services such as carbon, } \\
\text { forest nutrients, and biodiversity. }\end{array}$ & Qian et al., 2016 [54] \\
\hline
\end{tabular}

Table 4. Common value assessment methods—-they can be divided into equivalent factor method and functional value methods.

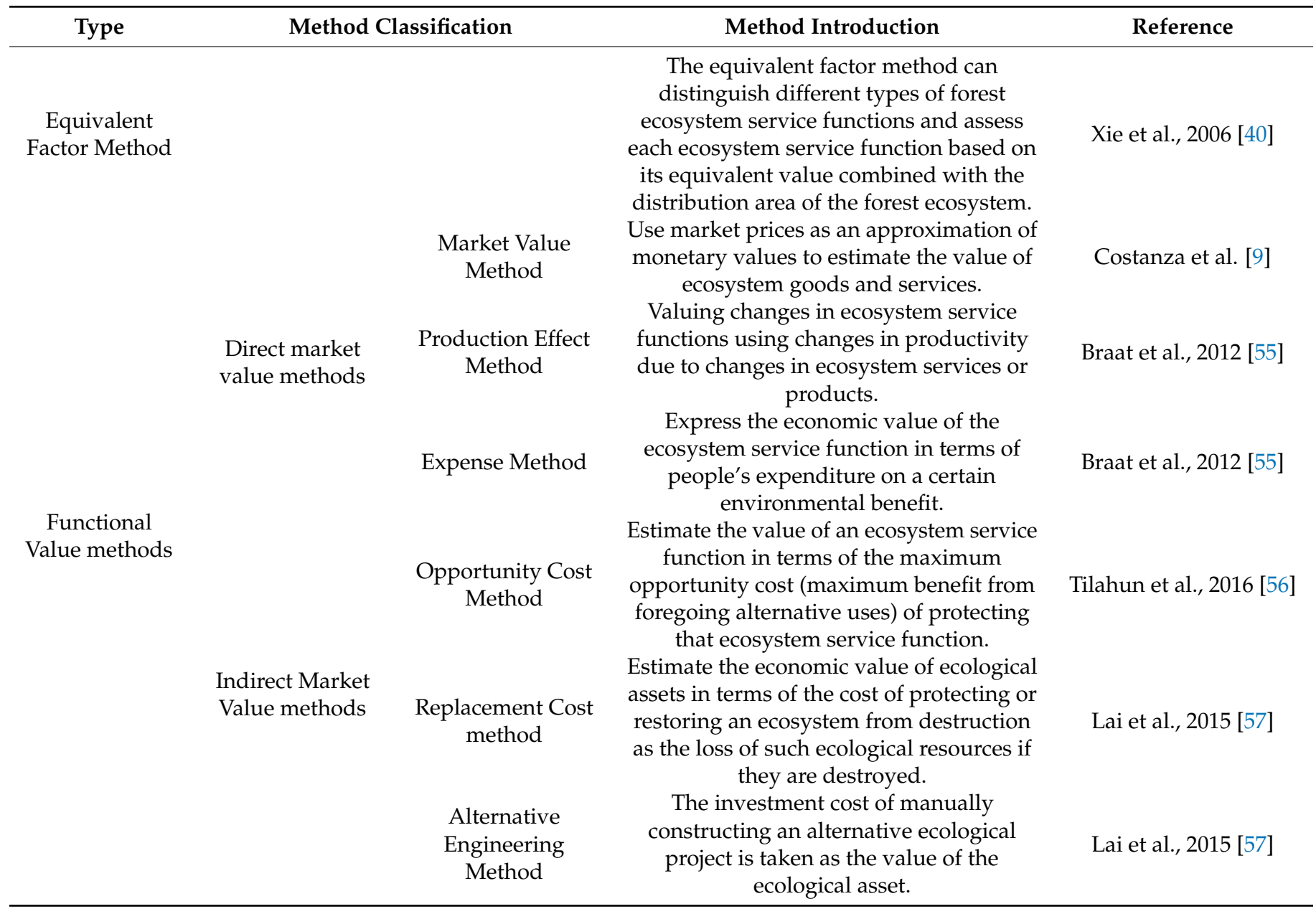


Table 4. Cont.

\begin{tabular}{|c|c|c|c|}
\hline Type & Method Classification & Method Introduction & Reference \\
\hline & $\begin{array}{c}\text { Enjoyment Value } \\
\text { Method } \\
\\
\text { Travel Expense } \\
\text { Method }\end{array}$ & $\begin{array}{l}\text { Using the potential value of item } \\
\text { characteristics, the impact of } \\
\text { environmental factors on price is } \\
\text { assessed by constructing a hedonic } \\
\text { price function with an equilibrium } \\
\text { relationship between product price } \\
\text { and product characteristics. } \\
\text { The cost of travel as an expression of } \\
\text { the intrinsic value of an ecosystem } \\
\text { service as a measure of preference for } \\
\text { a non-market product. } \\
\text { Estimating the economic value of an } \\
\text { ecosystem service function by directly } \\
\text { asking people about their willingness } \\
\text { to pay for an ecosystem service or } \\
\text { their willingness to accept } \\
\text { compensation for its loss. }\end{array}$ & Zhao et al., 2013 [59] \\
\hline
\end{tabular}

\subsection{FEA Accounting}

4.5.1. Single-Service Function Value Assessment

Many scholars have assessed the value of the single services of forest ecosystems. Robert-George et al. used data from forest management plans to assess the amount of carbon stored and sequestered in Retzat National Park, Romania, and calculated the monetary value of sequestered carbon based on carbon market prices [60]. Using a survey of the insurance premiums paid by farmers in Chilean agriculture, Eugenio et al. estimated the marginal value of one hectare of a forest ecosystem as a provider of local climate regulation as approximately USD 0.0733 [61]. The results of Dudek's study showed that the current recreational value of the state forests in Poland is estimated to be circa USD 8/ha [62]. Gerd et al. examined the recreation value of urban woodlands in Munich, Germany, and their results showed that the calculative monetary value of recreation reached up to EUR 15,440 per hectare per year [63]. Cholho et al. assessed the air purification value of Korean forests [26]. In addition, some scholars have done research on the value of forests for flood protection [64], and their values for the prevention of gravity-based natural disasters such as avalanches, mudslides, and rockfalls, etc., $[65,66]$.

\subsubsection{Assessing the Value of FEA Based on Region}

Scholars have conducted large numbers of studies on the valuation of FEA at different scales and in different regions, with administrative regions as the object. The reason for choosing administrative regions as the research object is that forestry statistics and forest resources inventory data are basically classified and summarized by administrative divisions, which makes it easy to obtain real and scientific raw data, and the data are relatively complete, comprehensive, and continuous. Many scholars have assessed and predicted the value of FEA in China [67-69]. Sepul et al. evaluated forest ecosystem services in Bangladesh and examined their implications for policy [70]. Morgan et al. estimated the local economic value of key ecosystem services provided by the Kakamega Rainforest and examined how the information can support sustainable forest management in Kenya [71]. Jon et al. estimated the spatially explicit economic values of a range of ecosystem services provided by the Brazilian Amazon, including food production, raw material provision, greenhouse gas mitigation, and climate regulation [33]. Ninan et al. valued forest ecosystem services and disservices in the Nagarhole National Park in Karnataka, India [12]. GIS to develop regional-scale maps for forest ecosystem services in northern Jordan, depicting the relative distribution of ecosystem service values by type (provisioning and cultural services), and exploring the relationship between social values and forest ES [72]. Negasi 
et al. studied the changes in ecosystem service values in response to land-use/land-cover dynamics in a dry Afromontane forest in northern Ethiopia [73]. Nitanan et al. evaluated the total economic value of forest ecosystem services in the tropical forests of Malaysia [74]. Diego et al. assessed the economic value of the Calden Forest in southern Córdoba Island through a willingness-to-pay survey [75].

\section{Key Scientific Issues to Be Solved Next}

5.1. Aiming to Solve the Inconsistency of the Concept of Ecological Assets and Accounting Content, and Clarifying the Relationships between Natural Capital, Ecological Assets, and Ecosystem Services

We must clarify the relationship between natural capital, ecological assets, and ES in response to the lack of uniformity in the concept and accounting content of ecological assets, and avoid double calculations. The current concept of ecological assets is not uniform, and the disputes are mainly concentrated in three aspects. Firstly, whether it should contain the flow component of natural capital. Secondly, whether it should contain the non-renewable resources of ES. Thirdly, whether it should contain ecosystem support services [76-78]. Therefore, we suggest that ecological capital should contain the flow part but exclude non-renewable resources and ecosystem support services. The reasons are as follows; firstly, non-renewable resources are not provided by current ecosystems; secondly, if non-renewable resources are included in ecological assets, it will duplicate the content of accounting for natural resource assets [79]; and thirdly, support services such as biodiversity maintenance do not directly contribute to human well-being, but rather reflect the benefits of ecosystems to humans in the form of increased productivity and enhanced scientific and educational aesthetic perceptions [80,81]. Consequently, supply, regulation, and cultural services should be accounted for in ecological asset accounting.

\subsection{Aiming to Resolve Which Aspects of the FEA Research Should Focus on, and Analyzing the Characteristics and Attributes of Ecological Assets from an Interdisciplinary Perspective}

We must explore which aspects of the main content of FEA research should be focused on in the future. Analyzing the characteristics and attributes of ecological assets from an interdisciplinary perspective can better grasp the research trends of FEA. FEA is an interdisciplinary field of forestry, ecology, economics, resources, and environmental sciences, and is a comprehensive and complex disciplinary system. Ecological asset assessment techniques also involve different systems such as fuzzy mathematics, computer technology, and geographic remote sensing technology, etc. The theoretical framework is constructed on an interdisciplinary basis so that the assessment results can more truly reflect the values of FEA [82]. Most of the current research on FEA account for the value of single services or total ecological assets in a region, which is the basic work of ecological assets research; however, it should not be the purpose and core of ecological assets research, it must be integrated with other social objectives so that the assessment work is finally integrated into the decision-making process, in order to contribute to the sustainable development of human society [83].

5.3. Aiming to Solve the Issue of the Construction of the Ecological Asset Evaluation Index System and the Selection of Evaluation Methods

In response to the issue of constructing an indicator system for FEA assessment, assessment indicators are selected at different spatial and temporal scales, combining the actual situation and research objectives. The role of indicators runs through the whole assessment process, and quantifiable indicators are the core of the calculation. The current methods rely too much on economic theory; traditional economics is based on the economic value theory of human market mechanism, which is not suitable for dealing with ecological problems [84]. The following research on evaluation indicators should firstly focus on comprehensively sorting out the indicators based on different types of forest ecosystems; secondly, provide indicator screening and application recommendations for different managements and beneficiaries; thirdly, for diversity and service indicators, perform an in-depth exploration of the relationship 
between services and service indicators; and finally, develop indicators that regulate services and cultural services, and develop indicators that are directly linked to human well-being [85]. Significant variability due to ecological location, environmental factors, tree species, and stand age should also be considered.

5.4. Aiming to Solve the Problem of Integrating Ecosystem Observation Techniques and Data Assimilation, Data Assimilation Methods That Integrate Ground-Positioning Observations, and Space Remote-Sensing Observations That Complement Each Other

For the integration of forest ecosystem observation-technology methods and data assimilation problems, the data assimilation methods of ground-based positioning observation and space-based remote-sensing observation are integrated to complement each other [36]. Ground-based observation is mainly to the achieve long-term observation of the ecosystem at the sample point/sample scale through positioning observation, and the observation time and space scale is small. Remote-sensing observation is mainly to achieve the rapid and macroscopic observation of ecosystems through the spectral characteristics of features, and the observation time and space scale is larger. The data information obtained from the two observation methods can complement each other well, but the observation mechanism and spatial and temporal scale characteristics of the two have significant differences. Integrating the two observation methods to achieve a more comprehensive and accurate observation of ecosystems is the key to providing comprehensive, scientific, and effective information-technology support for integrated ecosystem assessment [86].

\subsection{In View of the Problem of Spatial Heterogeneity in Ecological Asset Accounting, Conduct Dynamic Research}

In view of the characteristics of FEA with temporal and spatial heterogeneity, dynamic research is carried out. Early economic assessment studies mainly assumed spatial homogeneity across the study area [74]. Bateman et al. argue that this assumption is not ideal for accurate modeling because the real environment shows the variation of features throughout the space [87]. The value of ecosystem services is also characterized by temporal and spatial variability, and attention should be paid to a combination of historical, realistic, and predictive aspects, because large-scale areas, climate, elevation, soils, tree species, and management strategies also influence, and even determine, the function of forest ecosystems. Therefore, a dynamic study is needed to maintain and benefit from the forest [88]. Additionally, the transfer or transport of ecological capital needs to be considered for study in an open and complex system [76]. Currently, most studies do not consider the flow of forest ecological assets. Many ecological assets, such as forest products and water, are transported to different locations through trade, so import and export flows should also be considered in assessing forest ecological assets, and input-output analysis is a tool to study this issue [89].

\subsection{In View of the Current Forest Ecological Asset Accounting without Considering the Cost, Research the Net Value of Forest Ecological Assets}

Current accounting that does not consider costs only calculates the value of ecosystem service provision, leading to an overestimation of actual benefits [90]. This may negatively impact the development of environmental protection policies, land-use plans, and conservation plans. For example, China's national afforestation program has traditionally considered forests to be the appropriate ecological solution for all of China, one which would greatly increase the value of ecosystem services. However, planning for these programs has often failed to consider local constraints, such as whether precipitation in each region can support forest cover. In many cases, these constraints result in significant costs that greatly reduce the ecological and economic benefits of these projects [91]. Kinzig et al. defined the net value of ES as the net value after subtracting all costs from the value of ecological assets. In contrast, net value provides a more realistic assessment of the true value of ES and thus provides better support for environmental governance [92]. Afforestation should continue in areas with high net forest values, as the return on investment from 
these efforts will be high. On the contrary, areas with low or negative net forest values should consider other ecological restoration methods, such as grassland restoration [93]. Especially in karst rocky desertification areas, where soil erosion is serious and vegetation coverage is low, traditional rocky desertification control is to plant trees and forests, but now we should pay attention to the cost issue involved.

5.7. Aiming to Solve the Problem of FEA Appreciation and Preservation and Carrying Capacity Improvement Strategies, Sustainable Development Strategies Are Proposed According to Different Regions and Forest Types

The FCC, on the one hand, is the ability of the forest to survive, maintain, and regulate itself, and on the other hand, it also includes the amount of pressure the forest has on the activities of human society and civilization [94]. Accounting for FEA is to have a clearer understanding of the current state of forest ecology, with the goal of sustainable development. The development strategies of different periods, different regions, and different forest types should be different according to local conditions. We can use the adjustment of agroforestry structure, tree species ratio, and tree species structure to improve the material-product production capacity and environmental load effectiveness of the species and forest communities [95]. For example, ecological public welfare forests should focus on protection and improve ecological compensation mechanisms, while commercial forests should be scientifically managed and intensively operated [96]. The strategy of enhancing the carrying capacity of forestation in karst rock desertification control is proposed according to the ecological asset accounting results, with the ultimate goal of sustainable development of the forestation industry.

\section{Conclusions}

In this paper, we performed a systematic literature review by analyzing 317 articles retrieved from the Web of Science and CNKI. The main conclusions are as follows:

Firstly, searches on FEA are generally on the rise, and it can be seen that FEA are attracting more and more attention and discussion. After 2012, the trend of Chinese and English literature was different, with English literature growing faster than the Chinese literature because the relevant Chinese keywords shifted to ecosystem service values; on the other hand, Chinese scholars published more English papers. Secondly, the research on forest ecological assets is mainly conducted in China and USA; this indicates that forest ecosystem research is more emphasized in both countries and the number of published articles is comparative.

Thirdly, the literature keywords mapping showed that the most frequent words are related to service value and capacity, and that the ultimate goal of research on ecological assets is to enhance ecological carrying capacity and achieve sustainable development.

Lastly, this literature review has summarized several key scientific issues, these seven issues are hot research topics worthy of in-depth exploration in the future: the harmonizing of the definition of the concept of forest ecological assets; what should be the main focus of future research on forest ecological assets; the construction of an evaluation indicators system according to local conditions; the data assimilation methods of integrating ground-based positioning observations and space-based remote-sensing observations that complement each other; the study of the spatial and temporal heterogeneity of forest ecological assets; the study the net value of forest ecological assets; how to retain and increase the value of forest ecological assets; and how enhance the ecological carrying capacity of forests. These issues require further research.

Author Contributions: Conceptualization, K.X. and T.L.; methodology, Y.Q.; software, T.L.; data curation, H.L. and S.Y.; writing-original draft preparation, T.L.; writing-review and editing, Z.W.; project administration, K.X.; funding acquisition, K.X. All authors have read and agreed to the published version of the manuscript.

Funding: This research was funded by the Key Project of Science and Technology Program of Guizhou Province: Poverty Alleviation Model and Technology demonstration for Eco-industries Derivated 
from the karst desertification control, grant number 54112017; The 111 Project of National High School Discipline Innovation and Intelligence Introduction: Innovation and Intelligence Introduction Base for Karst Ecological Environment Discipline in South China, grant number D17016; The World Top Discipline Program of Guizhou Province: Karst Eco-environment Sciences, grant number 1252019.

Institutional Review Board Statement: Not applicable.

Informed Consent Statement: Not applicable.

Data Availability Statement: Data are contained within the article.

Conflicts of Interest: The authors declare no conflict of interest.

\section{References}

1. Millennium Ecosystem Assessment (MEA). Ecosystems and Human Well-Being: Synthesis; Island Press: Washington, DC, USA, 2005.

2. Ruckelshaus, M.H.; Jackson, S.T.; Mooney, H.A.; Jacobs, K.L.; Kassam, K.A.S.; Arroyo, M.T.K.; Baldi, A.; Bartuska, A.M.; Boyd, J.; Joppa, L.N.; et al. The IPBES global assessment: Pathways to action. Trends Ecol. Evol. 2020, 35, 407-414. [CrossRef]

3. Brockerhoff, E.G.; Barbaro, L.; Castagneyrol, B.; Forrester, D.I.; Gardiner, B.; Gonzalez-Olabarria, J.R.; Lyver, P.O.; Meurisse, N.; Oxbrough, A.; Taki, H.; et al. Forest biodiversity, ecosystem functioning and the provision of ecosystem services. Biodivers. Conserv. 2017, 26, 3005-3035. [CrossRef]

4. Li, H. Study on the Comprehensive Value Evaluation of Forest Ecology Assets of Longjiang Forest Industry Group. Master's Thesis, Northeast Forestry University, Harbin, China, 2011.

5. Keles, S.; Durusoy, I.; Cakir, G. Analysis of the changes in forest ecosystem functions, structure and composition in the Black Sea region of Turkey. J. Forest. Res. 2017, 28, 329-342. [CrossRef]

6. Tiemann, A.; Ring, I. Challenges and opportunities of aligning forest function mapping and the ecosystem service concept in Germany. Forests 2018, 9, 691. [CrossRef]

7. Unterberger, C.; Olschewski, R. Determining the insurance value of ecosystems: A discrete choice study on natural hazard protection by forests. Ecol. Econ. 2021, 180, 106866. [CrossRef]

8. Obeng, E.A.; Aguilar, F.X.; McCann, L.M. Payments for forest ecosystem services: A look at neglected existence values, the free-rider problem and beneficiaries' willingness to pay. Int. Forest. Rev. 2018, 20, 206-219. [CrossRef]

9. Costanza, R.; Arge, R.; de Groot, R.; Farber, S.; Grasso, M.; Hannon, B.; Limburg, K.; Naeem, S.; Oneill, R.V.; Paruelo, J.; et al. The value of the world's ecosystem service and natural capital. Nature 1997, 387, 253-260. [CrossRef]

10. Chang, Y.X.; Zou, T.H.; Yoshino, K. A new public appraisal method for valuating ecosystem services: A case study in the Wuyishan area, China. J. Clean. Prod. 2021, 286, 124973. [CrossRef]

11. Lehtoranta, V.; Sarvilinna, A.; Vaisanen, S.; Aroviita, J.; Muotka, T. Public values and preference certainty for stream restoration in forested watersheds in Finland. Water Resour. Econ. 2017, 17, 56-66. [CrossRef]

12. Ninan, K.N.; Kontoleon, A. Valuing forest ecosystem services and disservices-Case study of a protected area in India. Ecosyst. Serv. 2016, 20,1-14. [CrossRef]

13. Shi, J.; Zhang, P.D. Forest ecosystem services and their value evaluation of Ziwuling in Gansu province. Forest. Econ. 2007, 10, 68-71.

14. Su, X.Y. A Study on Forest Carrying Capacity. Ph.D. Thesis, Beijing Forestry University, Beijing, China, 2002.

15. Fino, S.R.; Williams, C.K.; Livolsi, M.C.; Ringelman, K.M.; Coluccy, J.M.; Devers, P.K.; Castelli, P.M. Carrying capacity of wintering American Black Ducks in forested wetlands. J. Wildl. Manag. 2017, 81, 943-950. [CrossRef]

16. Ismail, D.; Jiwan, D. Browsing preference and ecological carrying capacity of sambar deer (Cervus unicolor brookei) on secondary vegetation in forest plantation. Anim. Sci. J. 2015, 86, 225-237. [CrossRef]

17. Ouyang, X.Z.; Peng, S.K.; Liao, W.M. Approach to evaluating method for forest carrying capacity. Acta Agric. Univ. Jiangxiensis 2003, 25, 834-838.

18. De Prado, D.R.; San Martin, R.; Bravo, F.; De Aza, C.H. Potential climatic influence on maximum stand carrying capacity for 15 Mediterranean coniferous and broadleaf species. Forest. Ecol. Manag. 2020, 460, 117824. [CrossRef]

19. Hu, Y.; Li, Y.S. On the management of ecological capital and the construction of eco-service compensation mechanism. J. Fujian Agric. For. Univ. 2010, 163, 11-16.

20. Gao, J.X.; Fan, X.S. Connotation, traits and research trends of eco-assets. Res. Environ. Sci. 2007, 20, 137-143.

21. Muller, A.; Knoke, T.; Olschewski, R. Can existing estimates for ecosystem service values inform forest management? Forests 2019, 10, 132. [CrossRef]

22. Ouyang, Z.Y.; Zheng, H.; Xie, G.D.; Yang, W.; Liu, G.H.; Shi, Y.H.; Yang, D.G. Accounting theories and technologies for ecological assets, ecological compensation and scientific and technological contribution to ecological civilization. Acta Ecol. Sin. 2016, 36, 7136-7139.

23. Costanza, R. Valuing natural capital and ecosystem services toward the goals of efficiency, fairness, and sustainability. Ecosyst. Serv. 2020, 43, 101096. [CrossRef]

24. Hu, D. From produced (physical) asset to ecosystems asset-Complexity of asset and capital. Adv. Earth Sci. $2004,2,289-295$. 
25. Huang, X.W.; Chen, B.M. The theory and application of China eco-assets zoning. Acta Ecol. Sin. 1999, 19, $602-606$.

26. Song, C.; Lee, W.K.; Choi, H.A.; Kim, J.; Jeon, S.W.; Kim, J.S. Spatial assessment of ecosystem functions and services for air purification of forests in South Korea. Environ. Sci. Policy 2016, 63, 27-34. [CrossRef]

27. Lu, M.Q.; Cheng, J.Q.; Jin, C. Assessment of ecological assets for sustainable regional development: A case study of Deqing county, China. Sustainability 2017, 9, 939. [CrossRef]

28. Li, Y.; Li, H. Theoretical research on dynamic evaluation model of forest ecology assets. Intelligent information technology application association. In Proceedings of the 2011 International Conference on Future Computer Science and Application (FCSA 2011 V2), Kota Kinabalu, Malaysia, 16 July 2011; pp. 491-494.

29. Reineke, L.H. Perfecting a stand-density index for even-aged forests. J. Agric. Res. 1933, 46, 627-638.

30. Li, R.; Zhou, P.; Xin, X.S. Analysis of the environmental population carrying capacity of forest resources in Henan Province. Nandu Acad. Forum 1999, 3, 3-5.

31. Bo, W.J.; Wang, L.Y.; Cao, J.H.; Wang, X.K.; Xiao, Y.; Ouyang, Z.Y. Valuation of China's ecological assets in forests. Acta Ecol. Sin. 2017, 37, 4182-4190.

32. Dorji, T.; Brookes, J.D.; Facelli, J.M.; Sears, R.R.; Norbu, T.; Dorji, K.; Chhetri, Y.R.; Baral, H. Socio-cultural values of ecosystem services from oak forests in the eastern Himalaya. Sustainability 2019, 11, 2250. [CrossRef]

33. Strand, J.; Soares, B.; Costa, M.H.; Oliveira, U.; Ribeiro, S.C.; Pires, G.F.; Oliveira, A.; Rajao, R.; May, P.; Van der Hoff, R.; et al Spatially explicit valuation of the Brazilian Amazon forest's ecosystem services. Nat. Sustain. 2018, 1, 657-664. [CrossRef]

34. Rogan, J.; Chen, D. Remote sensing technology for mapping and monitoring land-cover and land-use change. Prog. Plann. 2004, 61, 301-325. [CrossRef]

35. Wang, B.; Niu, X.; Wei, W.J. National forest ecosystem inventory system of China: Methodology and applications. Forests 2020, 11, 732. [CrossRef]

36. Vargas, L.; Hein, L.; Remme, R.P. Accounting for ecosystem assets using remote sensing in the Colombian Orinoco River Basin lowlands. J. Appl. Remote Sens. 2017, 11, 026008. [CrossRef]

37. Tehrany, M.S.; Kumar, L.; Drielsma, M.J. Review of native vegetation condition assessment concepts, methods and future trends. J. Nat. Conserv. 2017, 40, 12-23. [CrossRef]

38. Huang, B.B.; Li, R.N.; Ding, Z.W.; O'Connor, P.; Kong, L.Q.; Xiao, Y.; Xu, W.H.; Guo, Y.N.; Yang, Y.Y.; Li, R.D.; et al. A new remote-sensing-based indicator for integrating quantity and quality attributes to assess the dynamics of ecosystem assets. Glob. Ecol. Conserv. 2020, 22, e00999. [CrossRef]

39. Costanza, R.; De Groot, R.; Braat, L.; Kubiszewski, I.; Fioramonti, L.; Sutton, P.; Farber, S.; Grasso, M. Twenty years of ecosystem services: How far have we come and how far do we still need to go? Ecosyst. Serv. 2017, 28, 1-16. [CrossRef]

40. Xie, G.D.; Lu, C.X.; Leng, Y.F. Ecological assets valuation of the Tibetan Plateau. J. Nat. Res. 2003, 18, $189-196$.

41. Li, L.; Wang, X.Y.; Luo, L.; Ji, X.Y.; Zhao, Y.; Zhao, Y.C.; Nabil, B. A systematic review on the methods of ecosystem services value assessment. Chin. J. Ecol. 2018, 37, 1233-1245.

42. Mancini, M.S.; Galli, A.; Coscieme, L.; Niccolucci, V.; Lin, D.; Pulselli, F.M.; Bastianoni, S.; Marchettini, N. Exploring ecosystem services assessment through Ecological Footprint accounting. Ecosyst. Serv. 2018, 30, 228-235. [CrossRef]

43. Roesch-McNally, G.E.; Rabotyagov, S.S. Paying for forest ecosystem services: Voluntary versus mandatory payments. Environ. Manag. 2016, 57, 585-600. [CrossRef]

44. Pan, H.S.; Li, Y.; Chen, Z.H. A review and perspectives on the methods for evaluation of forest ecosystem service values. J. Arid. Land Resour. Environ. 2018, 32, 72-78.

45. Watanabe, M.D.; Ortega, E. Dynamic emergy accounting of water and carbon ecosystem services: A model to simulate the impacts of land-use change. Ecol. Model. 2014, 271, 113-131. [CrossRef]

46. Tan, X.Y.; Hirabayashi, S.; Shibata, S. Estimation of ecosystem services provided by street trees in Kyoto, Japan. Forests 2021, 12, 311. [CrossRef]

47. Yuan, Z.; Wan, R. A review on the methods of ecosystem service assessment. Ecol. Sci. 2019, 38, $210-219$.

48. Yang, D.; Liu, W.; Tang, L.Y.; Chen, L.; Li, X.Z.; Xu, X.L. Estimation of water provision service for monsoon catchments of South China: Applicability of the InVEST model. Landsc. Urban Plan. 2019, 2, 133-143. [CrossRef]

49. Boumans, R.; Roman, J.; Altman, I.; Kaufman, L. The Multiscale Integrated Model of Ecosystem Services (MIMES): Simulating the interactions of coupled human and natural systems. Ecosyst. Serv. 2015, 3, 30-41. [CrossRef]

50. Villa, F.; Bagstad, K.J.; Voigt, B. A methodology for adaptable and robust ecosystem services assessment. PLoS ONE 2014, 9 , e91001. [CrossRef] [PubMed]

51. Bagstad, K.J.; Johnson, G.W.; Voigt, B. Spatial dynamics of ecosystem service flows: A comprehensive approach to quantifying actual services. Ecosyst. Serv. 2013, 4, 117-125. [CrossRef]

52. Ge, Y.Y.; Xin, B.Y.; Li, X. Urban forest construction based on ecosystem service function improvement in warm temperate semihumid areas. J. Beijing For. Univ. 2020, 42, 127-141.

53. Han, M.C.; Li, Z.Y. Ecological benefits evaluation of urban forest and its models. World For. Res. 2011, $24,42-46$.

54. Qian, H.; Field, R.; Zhang, J.L.; Zhang, J.; Chen, S.B. Phylogenetic structure and ecological and evolutionary determinants of species richness for angiosperm trees inforest communities in China. J. Biogeogr. 2016, 43, 603-605. [CrossRef]

55. Braat, L.C.; Groot, R.D. The ecosystem services agenda: Bridging the worlds of natural science and economics, conservation and development, and public and private policy. Ecosyst. Serv. 2012, 1, 4-15. [CrossRef] 
56. Tilahun, M.; Damnyag, L.; Anglaaere, L.C.N. The Ankasa Forest Conservation Area of Ghana: Ecosystem service values and on-site REDD + opportunity cost. For. Policy Econ. 2016, 73, 168-176. [CrossRef]

57. Lai, M.; Shaohong, W.U.; Yin, Y. Accounting for eco-compensation in the three -river headwaters region based on ecosystem service value. Acta Ecol. Sin. 2015, 35, 227-236.

58. Beier, C.M.; Caputo, J.; Lawrence, G.B. Loss of ecosystem services due to chronic pollution of forests and surface waters in the Adirondack region (USA). J. Environ. Manag. 2017, 191, 19-27. [CrossRef]

59. Zhao, J.L.; Wang, L.X.; Han, H.R.; Kang, F.F.; Zhang, Y.L. Research advances and trend in forest ecosystem services value evaluation. Chin. J. Ecol. 2013, 32, 2229-2237.

60. Pache, R.G.; Abrudan, I.V.; Nita, M.D. Economic valuation of carbon storage and sequestration in Retezat National Park, Romania. Forests 2021, 12, 43. [CrossRef]

61. Figueroa, E.; Pasten, R. The economic value of forests in supplying local climate regulation. Aust. J. Agric. Resour. Econ. 2015, 59, 446-457. [CrossRef]

62. Dudek, T. Forest recreation in annual balance sheet of a forest districts versus estimated recreational value of forests. Sylwan 2017, 16, 748-755.

63. Lupp, G.; Forster, B.; Kantelberg, V.; Markmann, T.; Naumann, J.; Honert, C.; Koch, M.; Pauleit, S. Assessing the recreation value of urban woodland using the ecosystem service approach in two forests in the Munich Metropolitan region. Sustainability 2016, 8 , 1156. [CrossRef]

64. Barth, N.C.; Doll, P. Assessing the ecosystem service flood protection of a riparian forest by applying a cascade approach. Ecosyst. Serv. 2016, 21, 39-52. [CrossRef]

65. Getzner, M.; Gutheil-Knopp-Kirchwald, G.; Kreimer, E.; Kirchmeir, H.; Huber, M. Gravitational natural hazards: Valuing the protective function of Alpine forests. For. Policy Econ. 2017, 80, 150-159. [CrossRef]

66. Brander, L.M.; Tankha, S.; Sovann, C.; Sanadiradze, G.; Zazanashvili, N.; Kharazishvili, D.; Memiadze, N.; Osepashvili, I.; Beruchashvili, G.; Arobelidze, N. Mapping the economic value of landslide regulation by forests. Ecosyst. Serv. 2018, 32, 101-109. [CrossRef]

67. Zhao, T.Q.; Ouyang, Z.Y.; Zheng, H.; Wang, X.K.; Miao, H. Forest ecosystem services and their valuation in China. J. Nat. Resour. 2004, 4, 480-491.

68. Yu, X.X.; Lu, S.W.; Jin, F. The assessment of the forest ecosystem services evaluation in China. Acta Ecol. Sin. 2005, 8, 2096-2102.

69. Wu, S.; Yan, X.D.; Zhang, L.J. The relationship between forest ecosystem emergy and forest ecosystem service value in China. Acta Geogr. Sin. 2014, 69, 334-342.

70. Barua, S.K.; Boscolo, M.; Animon, I. Valuing forest-based ecosystem services in Bangladesh: Implications for research and policies. Ecosystem Services. Ecosyst. Serv. 2020, 42, 101069. [CrossRef]

71. Mutoko, M.C.; Hein, L.; Shisanya, C.A. Tropical forest conservation versus conversion trade-offs: Insights from analysis of ecosystem services provided by Kakamega rainforest in Kenya. Ecosyst. Serv. 2015, 14, 1-11. [CrossRef]

72. Al-Assaf, A.A.; Al-Asmar, Y.Y.; Johnsen-Harris, B.D.; Al-Raggad, M.M. Spatial mapping of the social value of forest services: A case study of northern Jordan. J. Sustain. For. 2016, 35, 469-485. [CrossRef]

73. Solomon, N.; Segnon, A.C.; Birhane, E. Ecosystem service values changes in response to land-use/land-cover dynamics in dry afromontane forest in northern Ethiopia. Int. J. Environ. Res. Public Health 2019, 16, 4653. [CrossRef]

74. Nitanan, K.M.; Shuib, A.; Sridar, R.; Kunjuraman, V.; Zaiton, S.; Herman, M.A. The total economic value of forest ecosystem services in the tropical forests of Malaysia. Int. For. Rev. 2020, 22, 485-503. [CrossRef]

75. Tello, D.S.; de Prada, J.D.; Cristeche, E.R. Economic valuation of the Calden (Prosopis Caldenia Burkart) forest in the south of Cordoba, Argentina. Rev. Chapingo Ser. Cienc. For. Ambiente 2018, 24, 297-312. [CrossRef]

76. Yu, H.J.; Wang, Y.T.; Li, X.; Wang, C.D.; Sun, M.X.; Du, A.S. Measuring ecological capital: State of the art, trends, and challenges. J. Clean. Prod. 2019, 219, 833-845. [CrossRef]

77. Barbier, E.B. Wealth accounting, ecological capital and ecosystem services. Environ. Dev. Econ. 2013, 18, 133-161. [CrossRef]

78. Galli, A.; Halle, M.; Grunewald, N. Physical limits to resource access and utilisation and their economic implications in Mediterranean economies. Environ. Sci. Policy 2015, 51, 125-136. [CrossRef]

79. Feng, Z.M.; Yang, Y.Z.; Yan, H.M.; Pan, T.; Jiang, D.; Xiao, C.W. Issues regarding the compilation of the natural resource balance sheet. Resour. Sci. 2017, 39, 1615-1627.

80. Koch, E.W.; Barbier, E.B.; Silliman, B.R.; Reed, D.J.; Perillo, G.M.; Hacker, S.D.; Granek, E.F.; Primavera, J.H.; Muthiga, N.; Polasky, S.; et al. Non-linearity in ecosystem services: Temporal and spatial variability in coastal protection. Front. Ecol. Environ. 2009, 7 , 29-37. [CrossRef]

81. Liu, Y.X.; Fu, B.J.; Zhao, W.W.; Wang, S. Ecological asset accounting and ecosystem services evaluation: Concept intersection and key research priorities. Acta Ecol. Sin. 2018, 38, 8267-8276.

82. Lara-Pulido, J.A.; Guevara-Sangines, A.; Martelo, C.A. A meta-analysis of economic valuation of ecosystem services in Mexico. Ecosyst. Serv. 2018, 31, 126-141. [CrossRef]

83. Cao, J.J.; Wu, G.L.; Cao, S.Z.; Du, G.Z. Review on ecological system assets evaluation in China. Sci. Technol. Rev. 2007, 28, 65-74.

84. Bockstael, N.; Costanza, R.; Strand, I.; Boynton, W.; Bell, K.; Wainger, L. Ecological economic modeling and valuation of ecosystems. Ecol. Econ. 1995, 14, 143-159. [CrossRef] 
85. Fu, B.J.; Yu, D.D.; Lü, N. An indicator system for biodiversity and ecosystem services evaluation in China. Acta Ecol. Sin. 2017, 37, 341-348.

86. Liu, J.Y.; Yue, T.X.; Zhang, R.H.; Shao, Q.Q. Information technology support for ecosystem assessment. Resour. Sci. 2006, 30, 6-7.

87. Bateman, I.J.; Harwood, A.R.; Mace, G.M.; Watson, R.T.; Abson, D.J.; Andrews, B.; Binner, A. Bringing ecosystem services into economic decision-making: Land use in the United Kingdom. Science 2013, 341, 45-50. [CrossRef] [PubMed]

88. Mo, L.C.; Liu, J.K.; Chen, J.C.; Xie, Y. Quantifying ecosystem services of dominate forests in the Beijing mountain area. Environ. Sci. Pollut. Res. 2020, 27, 27773-27785. [CrossRef]

89. Wood, R.; Stadler, K.; Bulavskaya, T.; Lutter, S.; Giljum, S.; de Koning, A.; Kuenen, J.; Schutz, H.; Acosta-Fernandez, J.; Usubiaga, A.; et al. Global sustainability accounting-developing EXIOBASE for multi-regional footprint analysis. Sustainability 2015, 7, 138-163. [CrossRef]

90. Jacobs, S.; Dendoncker, N.; Martín-López, B.; Barton, D.N.; Gomez-Baggethun, E. A new valuation school: Integrating diverse values of nature in resource and land use decisions. Ecosyst. Serv. 2016, 22, 213-220. [CrossRef]

91. Chen, L.; Wang, X. Several key problems of biodiversity and forest ecosystem health. Chin. J. Ecol. 2008, 27, 816-820.

92. Kinzig, A.P.; Perrings, C.; Chapin, F.S.; Polasky, S.; Smith, V.K.; Tilman, D.; Turner, B.L. Paying for ecosystem services-Promise and peril. Science 2011, 334, 603-604. [CrossRef] [PubMed]

93. Cao, S.X.; Suo, X.H.; Xia, C.Q.; Yu, Z.Q.; Feng, F. Net value of forest ecosystem services in China. Ecol. Eng. 2020, $142,105645$. [CrossRef]

94. Wang, S.R. Study on forest carrying capacity in Beijing-Tianjin-Hebei integration. For. Econ. 2018, 40, 52-57.

95. Zhang, J. A study on forest carrying capacity in the region of low mountain and hills in Sichuan basin. J. Sichuan Agric. Univ. 1996, 14, 417-424.

96. Zheng, W.S. Evaluation of forest carrying capacity and sustainable management measures in Zhangping City. Mod. Agric. Sci. Technol. 2012, 13, 166-169. 